\title{
Matching effect on fatigue crack growth behaviour of high-strength steels GMA welded joints
}

\author{
János Lukács ${ }^{1}$ - Ádám Dobosy ${ }^{1}$ \\ Received: 22 October 2017 / Accepted: 15 June 2019 / Published online: 8 July 2019 \\ (C) The Author(s) 2019
}

\begin{abstract}
The objective of the paper is to study the influence of the mismatch effect on high-strength steels and to determine fatigue crack propagation design curves. In order for determination and comparison of the fatigue resistance, fatigue crack growth tests were performed on S690QL, S960QL quenched and tempered, and S960M thermomechanically rolled high-strength steels. Fifteenmillimeter- and 30-mm-thick base materials were used for our investigations. Welded joints were made from these base materials, using gas metal arc welding with matching, overmatching, and undermatching filler metals. In the paper, the performance of the welding experiments will be presented, especially with the difficulties of the filler material selection; along with the results of the fatigue crack growth examinations executed on the base materials and its welded joints. Statistical aspects were applied both for the presenting of the possible locations of the cracks in the base materials and the welded joints and for the processing of the measured data. Furthermore, the results will be compared with each other, and the possibility of derivation of fatigue crack propagation design or limit curves will be referred.
\end{abstract}

Keywords High-strength steels $\cdot$ GMA welding $($ GMAW) $\cdot$ Mismatch $\cdot$ Fatigue cracks $\cdot$ Design

\section{Introduction}

Nowadays, one of the basic trends of vehicle industry is the environmental impact reduction, in other words, the consumption reduction due to weight decreasing, which can be approached from materials science of view, by applying different high-strength materials [1] (steels [2-4], aluminium alloys [5], and composites [6]). In case of different vehicles, the main joining technology is the welding, the conventional and advanced methods of fusion and pressure welding. Beside the environmental impact reduction, the reliability and safety requirements according to structural elements of vehicles have significant grown; at the same time, statistical data show that third portion of damages leading to fracture occur in welded

Recommended for publication by Commission XIII - Fatigue of Welded Components and Structures

János Lukács

janos.lukacs@uni-miskolc.hu

1 Institute of Materials Science and Technology, Faculty of Mechanical Engineering and Informatics, University of Miskolc, Miskolc-Egyetemváros H-3515, Hungary joints, while their near four fifths happen to cyclic loaded structural elements.

During the welding process, the elements are affected with heat-effect and mechanical loads, which result in inhomogeneous welded joint [7]. The inhomogeneity of the welded joints appears both in microstructural and in geometrical aspects. In case of structural relation, zones with different microstructure and dissimilar behaviour come into being, in case of geometrical relation, it shows up in form as material discontinuities and locations for stress concentration. The changes in microstructure and geometry materialize in deflections (acceptable), or rather in failures (unacceptable); and these influence the behaviour of welded joints and their loadability. Discontinuities in materials have especially high danger in case of cyclic loading conditions, which are typical for vehicle structural elements.

All these together explain that our research work has focused on the high-strength steels from the world of materials, on the welding technologies from the manufacturing processes, and finally, on the cyclic loads from the different loading conditions. Different high-strength steels and the gas metal arc welding (GMAW) method were chosen; and the investigations were focused on fatigue crack growth (FCG) tests. Individual FCG test results can be found in the literature, the 
Table 1 The thicknesses of the base materials [mm], and the chemical composition of the base materials and filler metals (wt\%)

\begin{tabular}{lllllllllllll}
\hline Material designation & Thickness & $\mathrm{C}$ & $\mathrm{Si}$ & $\mathrm{Mn}$ & $\mathrm{Cr}$ & $\mathrm{Mo}$ & $\mathrm{Ni}$ & $\mathrm{S}$ & $\mathrm{P}$ & $\mathrm{Ti}$ & $\mathrm{V}$ & $\mathrm{Al}$ \\
\hline RUUKKI Optim 700QL & 30 & 0.14 & 0.30 & 0.96 & 0.60 & 0.19 & - & 0.002 & 0.009 & 0.02 & 0.005 & 0.05 \\
SSAB Weldox 700E & 15 & 0.14 & 0.30 & 1.13 & 0.30 & 0.167 & - & 0.001 & 0.007 & 0.009 & 0.01 & 0.03 \\
SSAB Weldox 960Q $^{\text {a) }}$ & 15 & 0.16 & 0.23 & 1.25 & 0.2 & - & 0.04 & 0.001 & 0.008 & 0.004 & 0.04 & 0.06 \\
VOESTALPINE Alform 960M & 15 & 0.09 & 0.32 & 1.63 & 0.59 & 0.29 & 0.03 & 0.001 & 0.009 & 0.016 & - & 0.041 \\
INEFIL NiMoCr $^{\text {b) }}$ & N/A & 0.08 & 0.50 & 1.60 & 0.30 & 0.25 & 1.50 & 0.007 & 0.007 & - & 0.09 & - \\
Thyssen UNION 85 & N/A & 0.07 & 0.68 & 0.61 & 0.29 & 0.61 & 1.73 & 0.010 & 0.006 & 0.08 & 0.01 & 0.01 \\
Thyssen UNION X90 & N/A & 0.1 & 0.8 & 1.8 & 0.35 & 0.6 & 2.3 & - & - & - & - & - \\
ESAB OK Tubrod 14.03 & N/A & 0.08 & 0.51 & 1.61 & 0.02 & 0.55 & 2.27 & - & - & - & 0.01 & - \\
Thyssen UNION X96 & N/A & 0.12 & 0.80 & 1.90 & 0.45 & 0.55 & 2.35 & - & - & - & - & - \\
\hline
\end{tabular}

${ }^{\text {a) }} \mathrm{Cu}=0.01, \mathrm{Nb}=0.016, \mathrm{~B}=0.001, \mathrm{~N}=0.003 ;{ }^{\text {b) }} \mathrm{Cu}=0.12 ;{ }^{\mathrm{c})} \mathrm{Cu}=0.06 ;{ }^{\text {d) }} \mathrm{Cu}=0.02$

effect of stress ratio $(R)$ was investigated and compared on S355 and S690 Q + T steel grades [8]; and the effect of water quenching (in other words the different microstructure) was tested on RD480 steel [9]. The mismatch effect and other influencing factors on fatigue life were studied on HSLA-80 steel, each specimen on undermatching, matching (or equal matching), and overmatching welded conditions were investigated [10-12]. In our research work, statistical approach was applied during both the preparation and the evaluation of the investigations, which have been allowed the expansion the effectual range of the results and the increasing of reliability.

The paper summarizes and presents the results according to our FCG investigations on different quenched and tempered $(\mathrm{Q}+\mathrm{T})$ and thermomechanically rolled (TM) high-strength steel base materials (BM) and their GMAW joints (WJ). Different mismatch conditions were applied during the welding process; therefore, specimens from matching (m), overmatching (om), and undermatching (um) welded joints were tested. Furthermore, we also refer to the possibility of derivation of fatigue crack propagation design or limit curves cover all cases.

\section{Mismatch effect, materials, welding characteristics, and fatigue crack growth tests circumstances}

\subsection{Mismatch effect}

The selection of the filler metal in case of the high-strength steels is a very important and complex task. Thin advanced high-strength steel (AHSS) sheets can be successfully welded without filler metal, although in some cases, it may be disadvantageous to the weld quality (cracking phenomena, reaching the strength level). It is necessary to take into consideration that in the case of the examined steels, filler metal cannot be ignored; therefore, based on the ratio of the mechanical properties of base material and filler metal, matching (m), overmatching (om), and undermatching (um) filler metals can be used. In case of matching condition, the evolved mechanical properties of the joint are equal or nearly the same as the base material. In the undermatching case, the mechanical properties of the joint are lower than the base material properties, while in case of
Table 2 The mechanical properties of the examined base materials and filler metals

\begin{tabular}{lllll}
\hline Material designation & $\begin{array}{l}\text { Yield } \\
\text { strength } \\
(\mathrm{MPa})\end{array}$ & $\begin{array}{l}\text { Tensile } \\
\text { strength } \\
(\mathrm{MPa})\end{array}$ & $\begin{array}{l}\text { Elongation } \\
(\%)\end{array}$ & $\begin{array}{l}\text { Charpy V impact energy } \\
\left(-40^{\circ} \mathrm{C}\right) \\
(\mathrm{J})\end{array}$ \\
\hline RUUKKI Optim 700QL & 783 & 826 & 19 & 54 \\
SSAB Weldox 700E & 791 & 836 & 17 & 165 \\
SSAB Weldox 960Q & 1030 & 1076 & 16 & 56 \\
VOESTALPINE Alform & 1051 & 1058 & 17 & 177 \\
$\quad$ 960M & $\geq 750$ & $\geq 820$ & $\geq 19$ & $\geq 60$ \\
INEFIL NiMoCr & $\geq 790$ & $\geq 880$ & $\geq 16$ & $\geq 53$ \\
Thyssen UNION 85 & $\geq 890$ & $\geq 950$ & $\geq 15$ & $\geq 58$ \\
Thyssen UNION X90 & 757 & 842 & 23 & 71 \\
ESAB OK Tubrod 14.03 & $\geq 930$ & $\geq 980$ & $\geq 14$ & $\geq 40$ \\
Thyssen UNION X96 & & & & \\
\hline
\end{tabular}


Table 3 The base material-filler metal pairing during our experiments

\begin{tabular}{lll}
\hline Base material & Filler metal & Mismatch condition \\
\hline RUUKKI Optim 700QL & INEFIL NiMoCr & Matching (m) \\
SSAB Weldox 700E & Thyssen UNION X85 & Matching (m) \\
SSAB Weldox 700E & Thyssen UNION X90 & Overmatching (om) \\
SSAB Weldox 960Q & Thyssen UNION X96 & Matching (m) \\
SSAB Weldox 960Q & ESAB OK Tubrod 14.03 & Undermatching (um) \\
VOESTALPINE Alform 960M & Thyssen UNION X96 & Matching (m) \\
VOESTALPINE Alform 960M & Thyssen UNION X90 & Undermatching (um) \\
\hline
\end{tabular}

overmatching condition, the joint properties are higher than the base material features.

General theorem, that in the case of the hot-rolled steels, equal or slightly higher strength matching filler metals are used. In case of higher strength, overmatching filler metals necessary to count on high residual stress, which can be unfavourable. In case of high-strength steels (yield strength over $600 \mathrm{MPa}$ ), it is more beneficial to use undermatching filler metals. Of course, in that case, lower strength-welded joint was gained. Notwithstanding the smaller strength, these filler metals have a number of advantages, which can be used effectively on high-strength steels. Such positive attributes are the higher toughness of the weld metal, the higher resistance against the hydrogen cracking or the smaller residual stress in the welded joint. It calls for comment, that the mechanical properties of the welded joint exceed the minimal requirements of the base material in the case of undermatching filler metal [13]. Besides the previous mentioned benefits, the location of the welded joint in the structure or in the structural element is very important, too. On those places, where the joint is load-carrying, essential that the strength of the joint is equal the base material strength. However, on those places where the loading is lower (not load-carrying joints), it may be enough to use smaller strength joints.

Because of the higher strength weld metal, overmatching filler metals are used as well in many cases. In that case, the higher yield strength of the welded joint is more beneficial, despite the slightly higher residual stress, the lower toughness, or the decreasing of the fatigue, in our case of the FCG resistance. However, in that case, the ratio of the fatigue resistance reduction (if there is any) is unknown. Therefore, this study mainly focuses on this phenomenon. On the other hand, overmatched filler metals can be used only for lower yield strength high-strength steels, e.g. for S690Q type steels.
Fig. 1 Edge preparations and weld deposition sequences for 15 $\mathrm{mm}$ and 30 -mm-thick plates
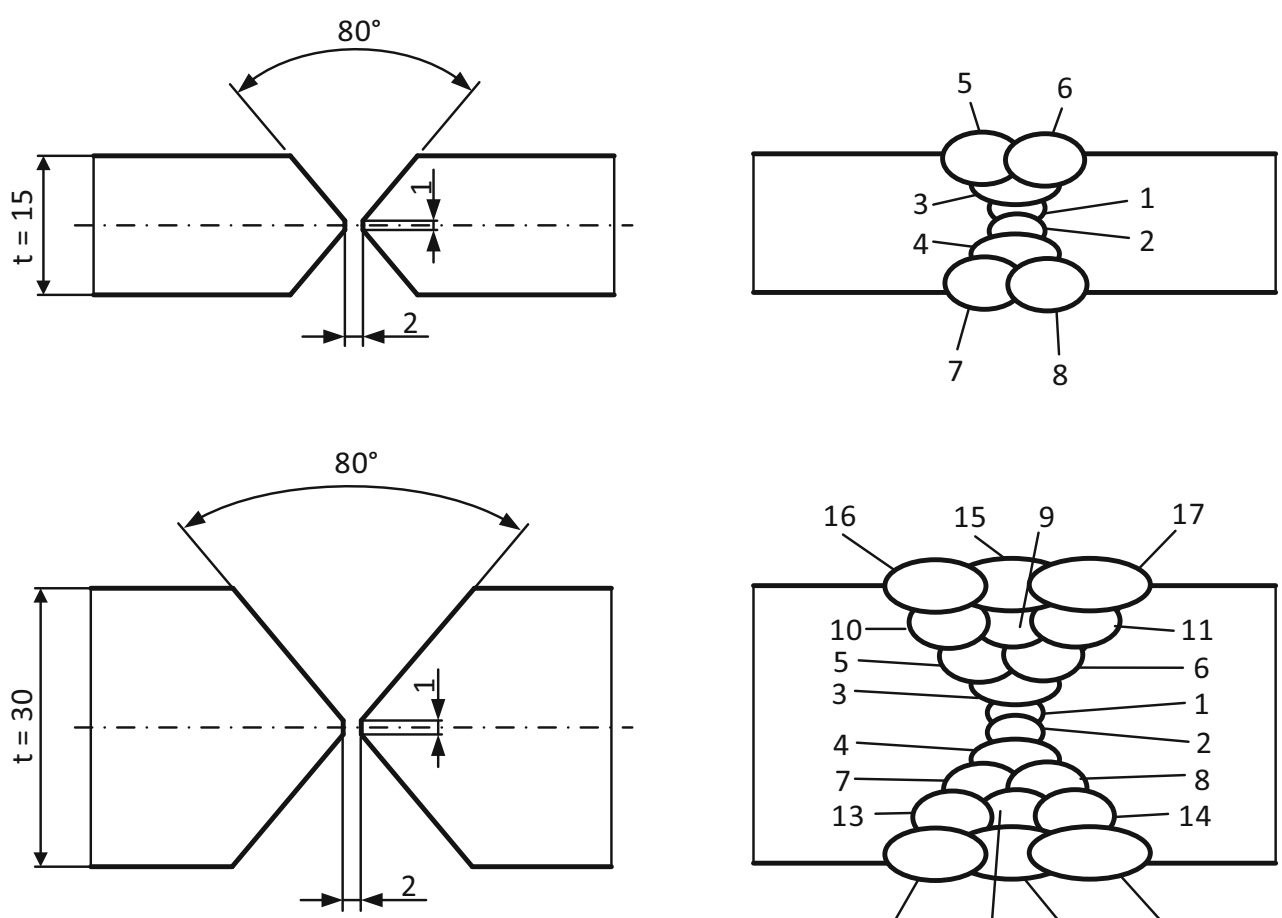


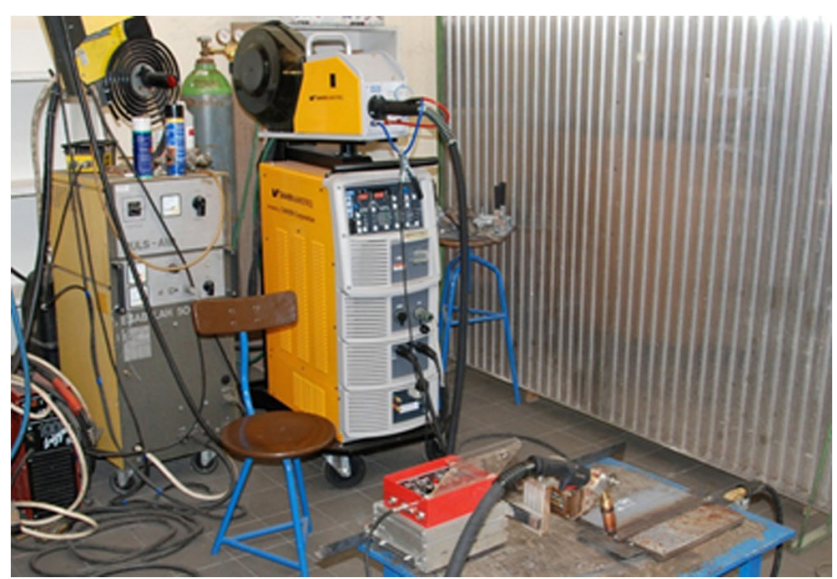

Fig. 2 Assembly of the welding experiments

\subsection{Base materials and filler metals}

The thicknesses of the investigated base materials, the chemical composition of the base materials and the selected filler metals, and the mechanical properties for the whole research program can be seen in Tables 1 and 2, respectively. The cases of the base material-filler metal pairing and therefore the mismatch conditions can be seen in Table 3 .

\subsection{Gas metal arc welding characteristics}

The applied welding equipment was a DAIHEN VARSTROJ WELBEE P500L power source. The dimensions of the welded plates were $300 \mathrm{~mm} \times 125 \mathrm{~mm}$. For the equal stress distribution $X$-grooved (double $V$-grooved) welding joints were used, with $80^{\circ}$ opening angle and with $2 \mathrm{~mm}$ gap between the two plates. Figure 1 illustrates the edge preparations and the weld deposition sequences for both $15-\mathrm{mm}$ - and 30mm-thick plates.

During the welding, the test pieces were rotated after each layer. Based on the industrial experience, $18 \% \mathrm{CO}_{2}+82 \% \mathrm{Ar}$ gas mixture (M21) was used as shielding gas. In the case of the filler metal, 1.2-mm-diameter wires were applied in all cases. The root layers ( 2 layers for both thicknesses) were made by a qualified welder; while the other layers (6 layers
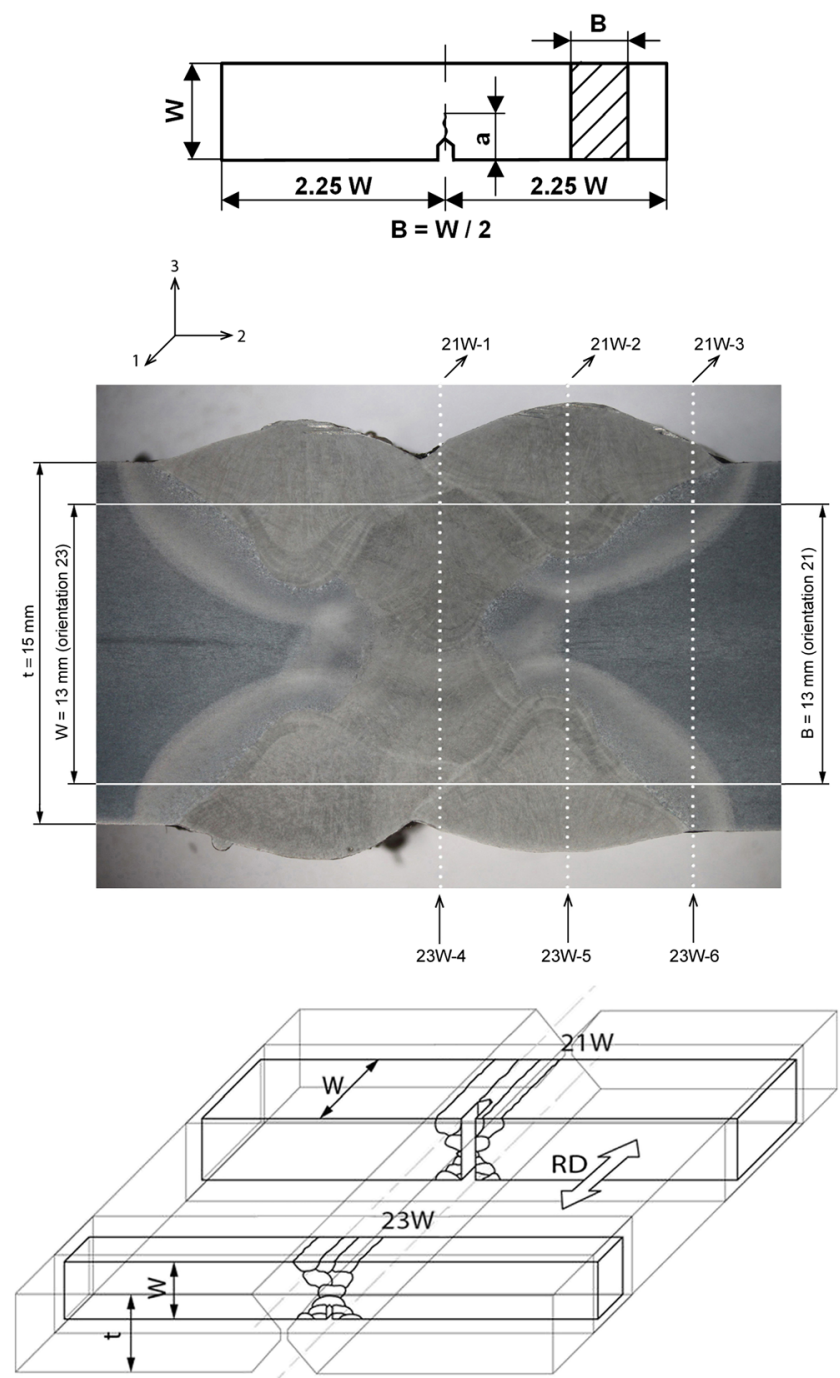

Fig. 3 TPB specimen configuration and location of the specimens in the welded joint with the notch directions ( $21 \mathrm{~W}$ and $23 \mathrm{~W}$ ) and crack paths ( $\mathrm{RD}$, rolling direction)

for $15-\mathrm{mm}$ - and 18 layers for 30-mm thicknesses) were made by automated welding car. The experimental assembly can be seen in Fig. 2.

Table 4 The applied welding parameters

\begin{tabular}{|c|c|c|c|c|c|c|c|}
\hline Base material designation & Layer & $\begin{array}{l}T_{\text {pre }}, T_{\text {ip }} \\
\left({ }^{\circ} \mathrm{C}\right)\end{array}$ & $\begin{array}{l}I \\
\text { (A) }\end{array}$ & $\begin{array}{l}U \\
(\mathrm{~V})\end{array}$ & $\begin{array}{l}v_{w} \\
(\mathrm{~cm} / \\
\mathrm{min})\end{array}$ & $\begin{array}{l}E_{v} \\
(\mathrm{~J} / \mathrm{mm})\end{array}$ & $\begin{array}{l}t_{8.5 / 5} \\
(\mathrm{~s})\end{array}$ \\
\hline RUUKKI Optim 700QL / & $1-2$ & 150 & $130-140$ & $19.0-20.5$ & 20 & $700-750$ & $7-8$ \\
\hline SSAB Weldox 700E & $3-20 / 8$ & 180 & $280-300$ & $28.5-28.5$ & 40 & $1000-1100$ & $9-11$ \\
\hline \multirow[t]{2}{*}{ SSAB Weldox 960Q } & $1-2$ & 180 & $120-130$ & $18.5-19.0$ & 20 & $570-590$ & $5-6$ \\
\hline & $3-8$ & 150 & $280-305$ & $28.5-29.0$ & 45 & $900-1000$ & $7.5-8.5$ \\
\hline \multirow[t]{2}{*}{ VOESTALPINE Alform 960M } & $1-2$ & 60 & $130-140$ & $19.0-20.5$ & 20 & $700-750$ & $7-8$ \\
\hline & $3-8$ & 150 & $270-300$ & $27.0-28.0$ & $30-45$ & $900-1400$ & $7-15$ \\
\hline
\end{tabular}


Fig. 4 Results of FCG tests executed on Weldox 700E base material in different orientations

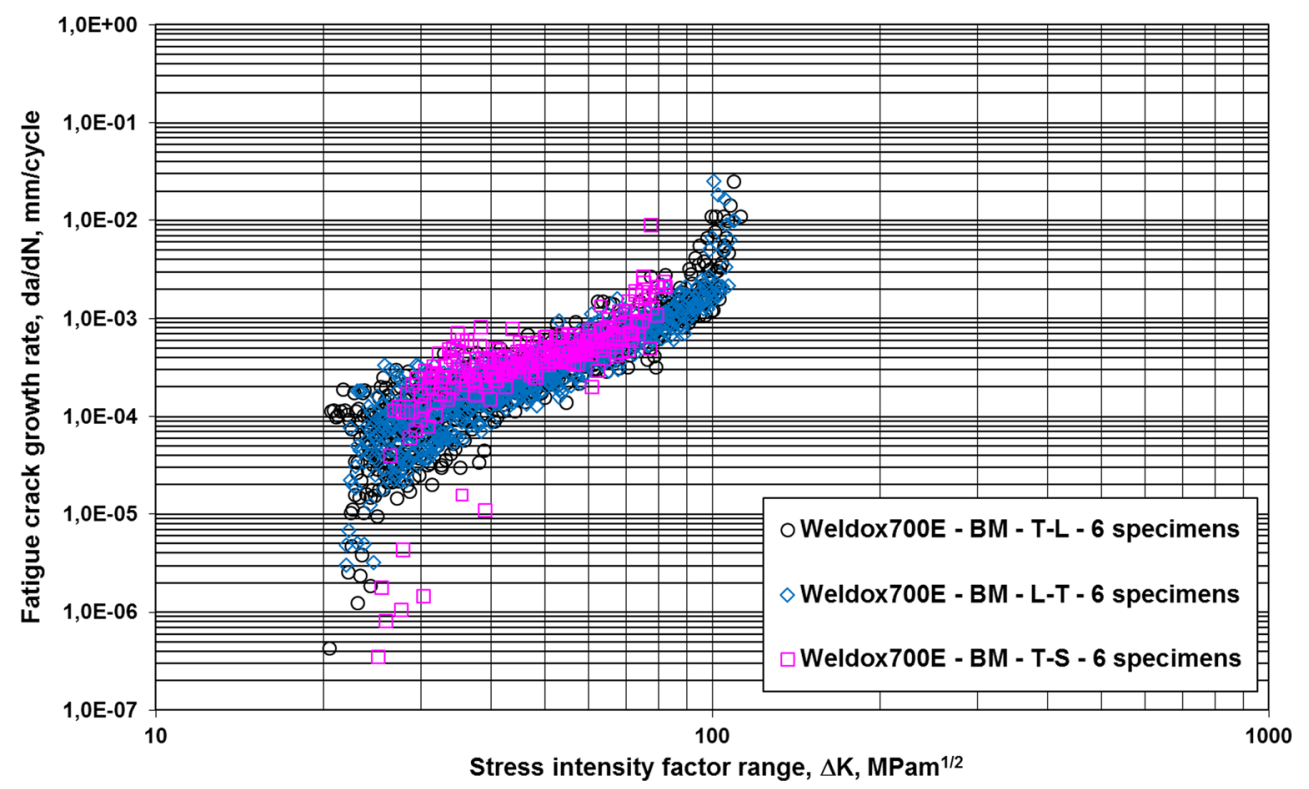

The welding parameters were selected based on both theoretical considerations [14-16] and real industrial applications. The applied welding parameters were summarized in Table 4 . The table shows the welding current $(I)$, the voltage $(U)$ and the welding speed $\left(v_{w}\right)$ values, also the preheating $\left(T_{\text {pre }}\right)$ and the interpass $\left(T_{\mathrm{ip}}\right)$ temperatures, with the linear energy $\left(E_{v}\right)$ and the calculated critical cooling time $\left(t_{8.5 / 5}\right)$ values. The critical cooling time was calculated as follows:

$t_{8.5 / 5}=\frac{E_{v}^{2}}{4 \pi \lambda c_{p} \varrho t^{2}}\left[\frac{1}{\left(500-T_{\mathrm{pre}}\right)^{2}}-\frac{1}{\left(850-T_{\mathrm{pre}}\right)^{2}}\right]$,

where $\lambda$ is the thermal conductivity coefficient, $c_{p}$ is the specific heat capacity, $\rho$ is the density of the base materi$\mathrm{al}$, and $t$ is the plate thickness. The parameters of the root and the filler layers in Table 4 were shown separately in each case.

\subsection{Fatigue crack growth test circumstances}

The FCG tests were executed on three-point bending (TPB) specimens, nominal $W$ values were $26 \mathrm{~mm}$ and $13 \mathrm{~mm}$ for both base materials and welded joints. The position of the notches correlated with the rolling direction (T-L, L-T, T-S,
Fig. 5 Results of FCG tests executed on Weldox 700E matching and overmatching welding conditions in $21 \mathrm{~W}$ orientation

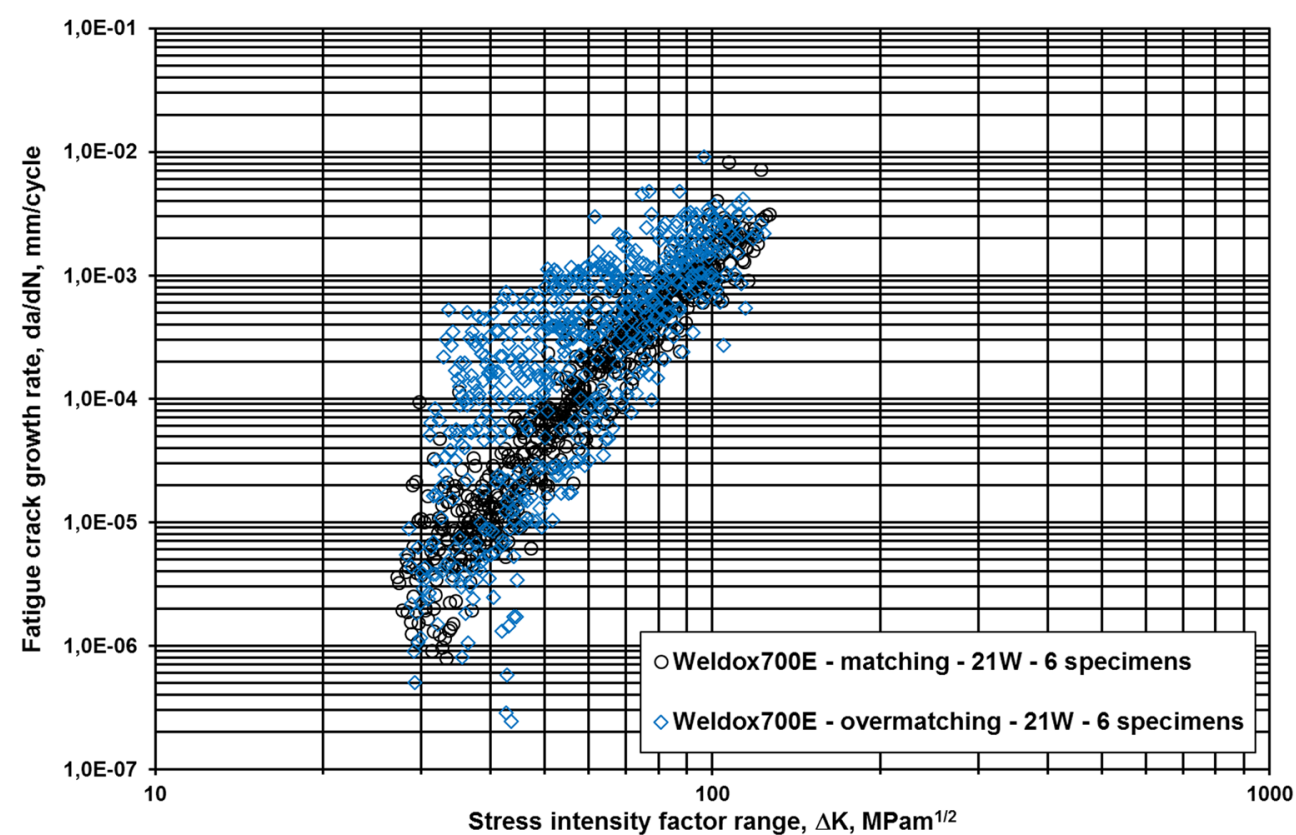


Fig. 6 Results of FCG tests executed on Weldox 700E matching and overmatching welding conditions in $23 \mathrm{~W}$ orientation

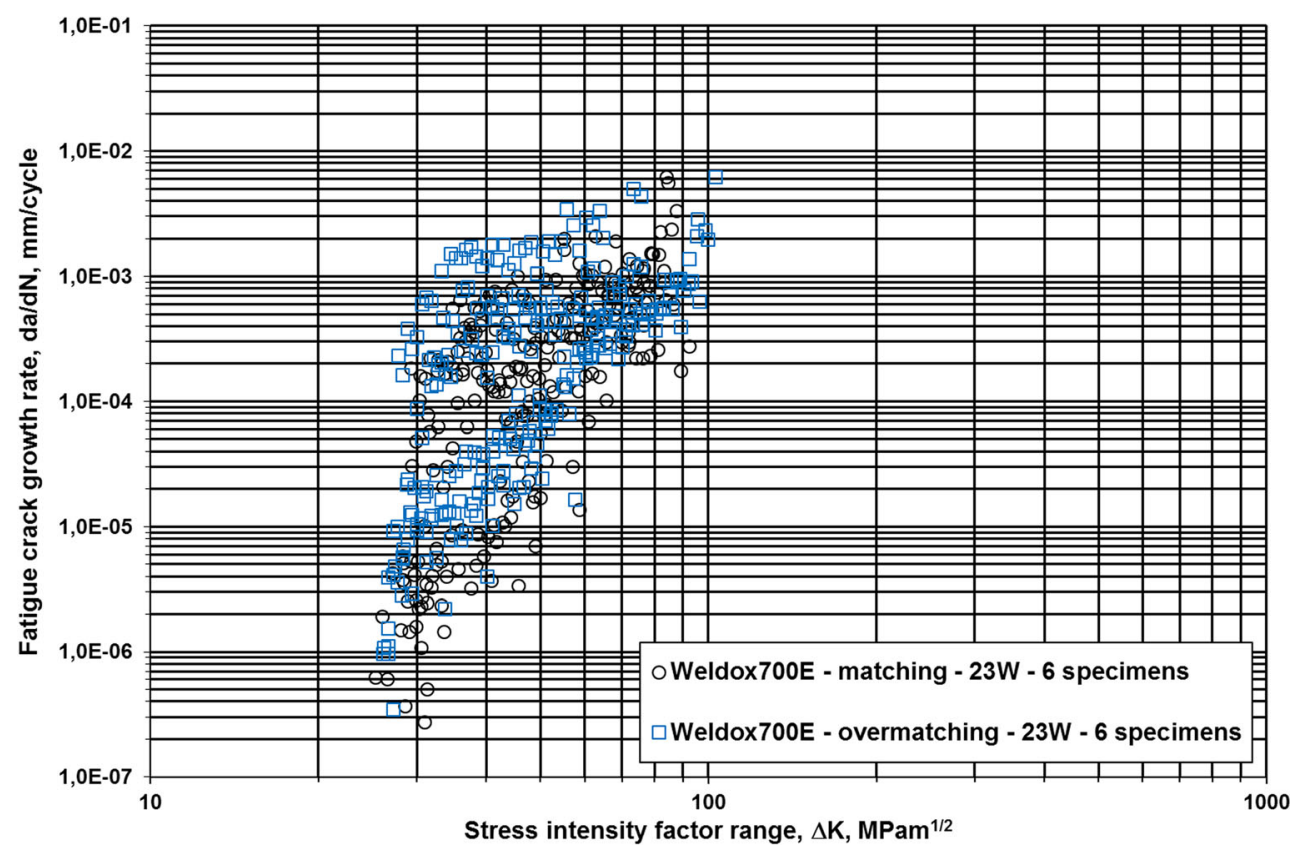

and L-S). The TPB specimen configuration and the positions of the cut specimens from the welded joints are shown in Fig. 3, 21 and 23 directions (21 W and $23 \mathrm{~W}$ ) were used. The notch locations, the notch distances from the centreline of the welded joints, were different; therefore, the positions of the notches and the crack paths represent the most important and the most typical crack directions in a real welded joint. Post-weld heat treating was not applied after welding on GMAW joints (investigations in as-welded condition).

The FCG examinations were performed with tensile stress, $R=0.1$ stress ratio, sinusoidal loading wave form, at room temperature, and on laboratory air, using MTS type electrohydraulic testing equipment. The loading frequency was different, it was $f=20 \mathrm{~Hz}$ at the two-thirds of crack growth, and it was $f=5 \mathrm{~Hz}$ at the last third. The propagating crack was registered with optical method, using video camera, hundredfold magnification $(N=\times 100)$.

\section{Results of examinations}

Stress intensity factor range $(\Delta K)$ values were calculated as follows:

$$
\Delta K=\frac{\Delta F}{B \sqrt{W}} Y\left(\frac{a}{W}\right),
$$

Fig. 7 Results of FCG tests executed on Weldox 960Q base material in different orientations

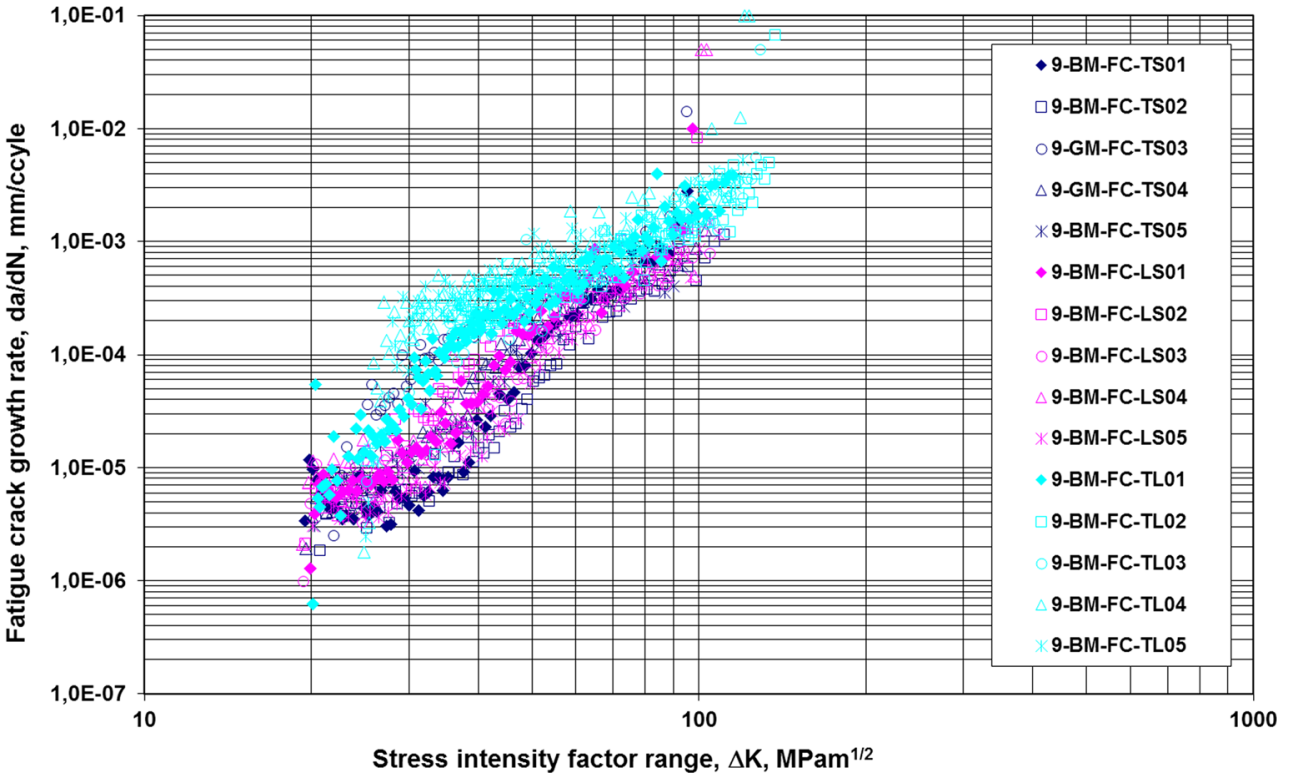


Fig. 8 Results of FCG tests executed on Weldox 960Q matching $(\mathrm{m})$ welding conditions in $21 \mathrm{~W}$ and $23 \mathrm{~W}$ orientations

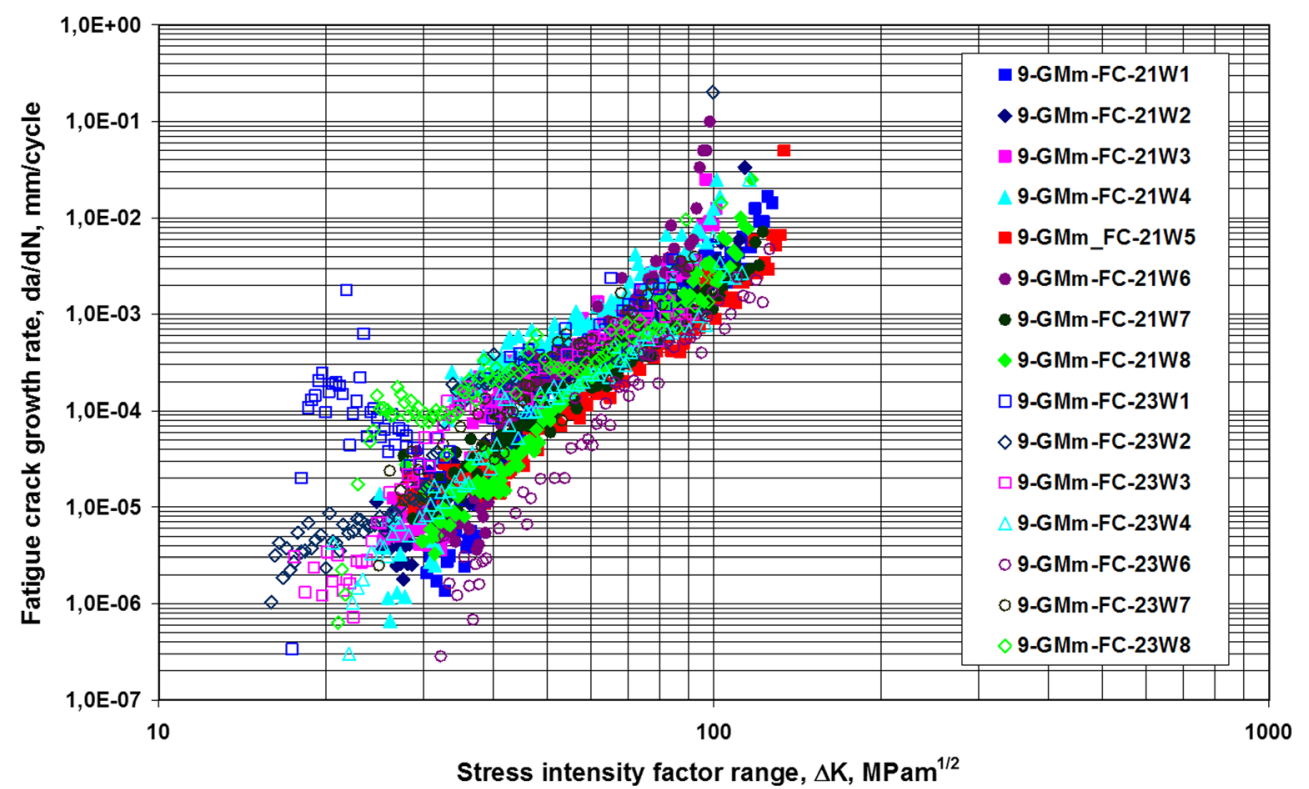

where

$$
\begin{aligned}
& Y\left(\frac{a}{W}\right) \\
& \quad=6\left(\frac{a}{W}\right)^{\frac{1}{2}}\left[1.93-3.07\left(\frac{a}{W}\right)+14.53\left(\frac{a}{W}\right)^{2}-25.11\left(\frac{a}{W}\right)^{3}+25.8\left(\frac{a}{W}\right)^{4}\right]
\end{aligned}
$$

and $\Delta F$ is the load range, $W$ is the specimen width, $B$ is the specimen thickness, and $a$ is the crack length. Secant method [17] was used to evaluate the fatigue crack growth data. The constants $(C$ and $n$ ) of the Paris-Erdogan relationship [18] were calculated using the least squares regression method, and the fatigue fracture toughness $\left(\Delta K_{f c}\right)$ values were determined using the crack length on the crack front measured by stereo microscope. The data belonging to stage II of the kinetic diagram of fatigue crack propagation have been eliminated during the least square regression analysis, for each specimen, systematically. The next figures and tables show our selected experimental results on Weldox 700E, Weldox 960Q, and Alform 960M base materials and their welded joints.

The calculated stress intensity factor range vs. fatigue crack growth rate values for Weldox 700E base material, and matching and overmatching cases of their welded joints in different orientations are shown in Fig. 4 (T-L, L-T, and T-S), and in Fig. 5 (21 W) and Fig. $6(23 \mathrm{~W})$, respectively.

The calculated stress intensity factor range vs. fatigue crack growth rate values for Weldox 960Q base material
Fig. 9 Results of FCG tests executed on Alform 960M base material in different orientations

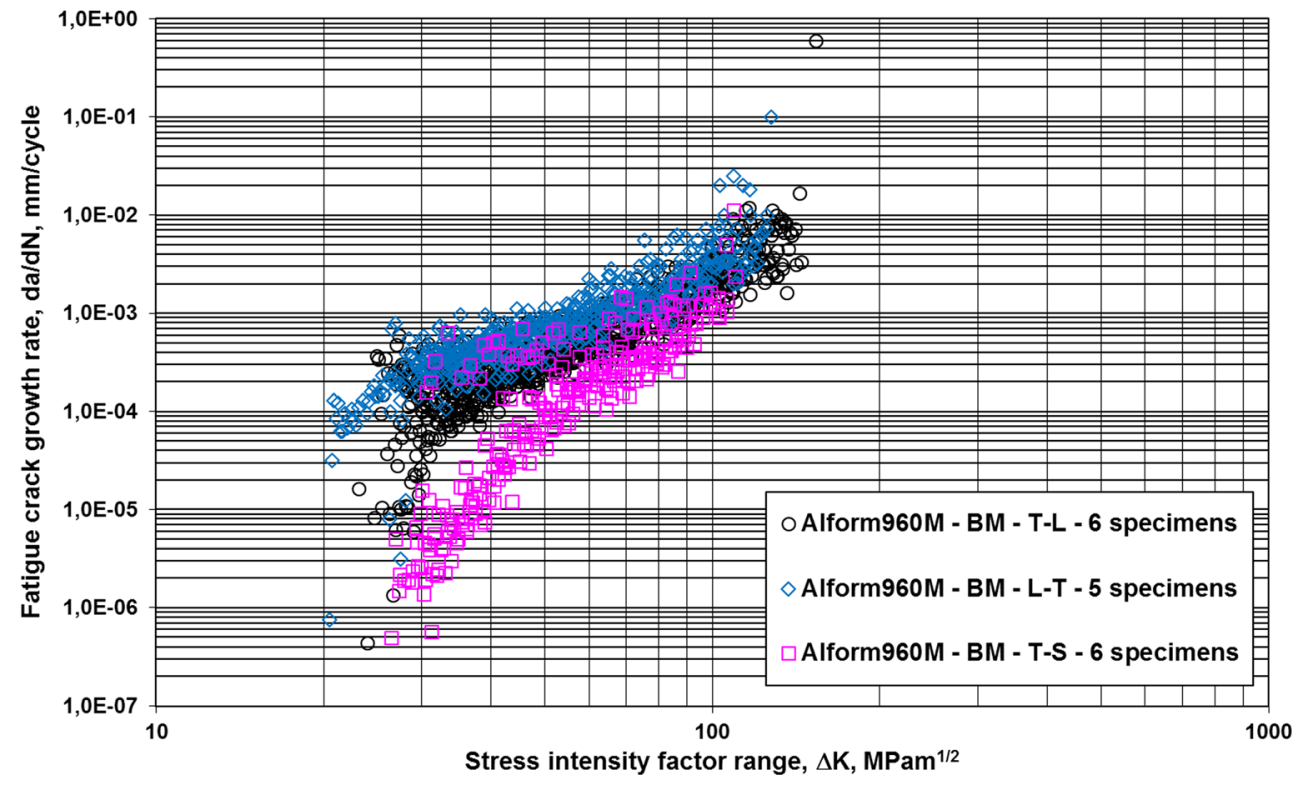


Fig. 10 Results of FCG tests executed on Alform 960M matching and undermatching welding condition in $21 \mathrm{~W}$ orientation

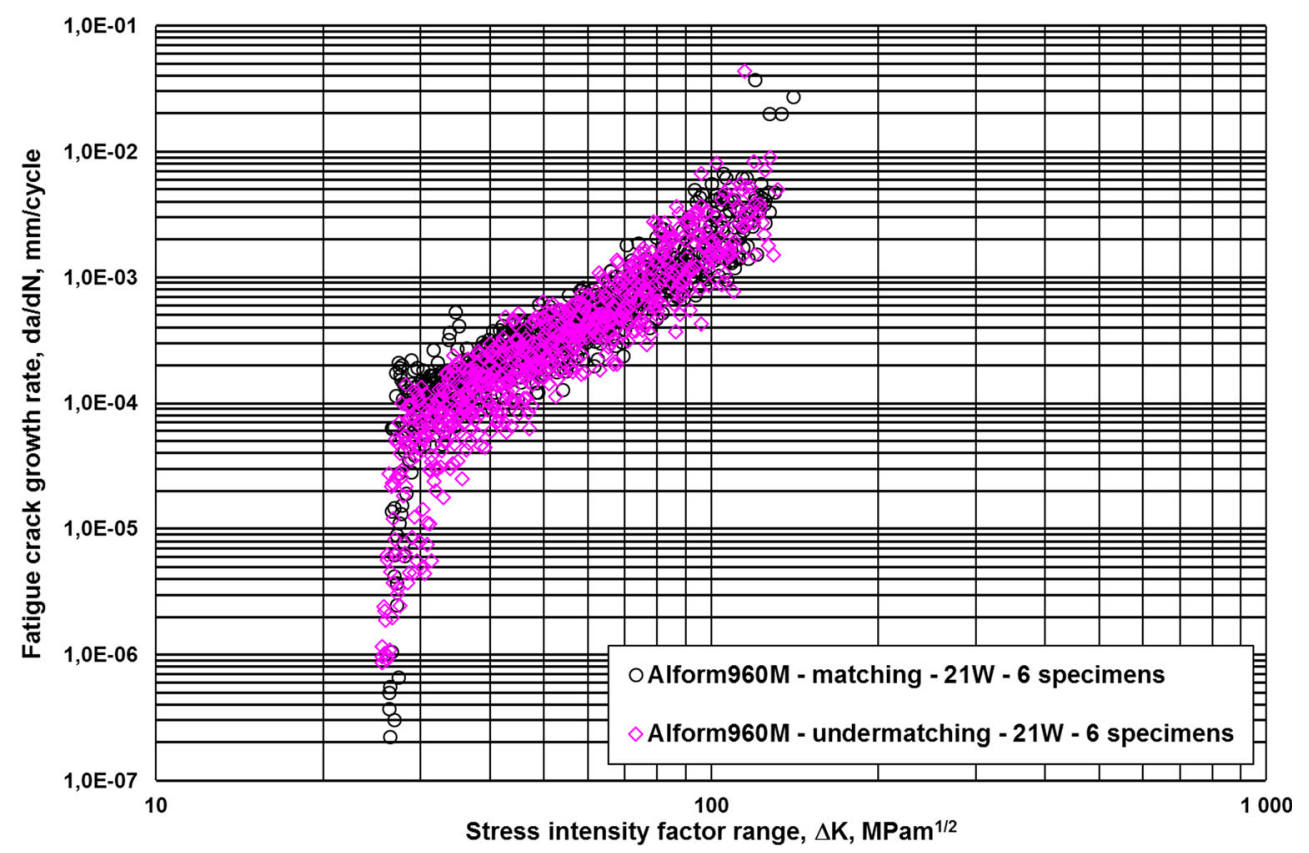

and matching case of their welded joints in different orientations are shown in Fig. 7 (T-S, L-S, and L-T) and in Fig. $8(21 \mathrm{~W}$ and $23 \mathrm{~W})$, respectively.

The calculated stress intensity factor range vs. fatigue crack growth rate values for Alform 960M base material, and matching and undermatching cases of their welded joints in different orientations are shown in Fig. 9 (T-L, L-T, and T-S), and in Fig. 10 (21 W) and Fig. 11 (23 W), respectively.

Tables 5, 6, and 7 summarize the characteristics of the Paris-Erdogan exponent $(n)$ and the fatigue fracture toughness $\left(\Delta K_{f c}\right)$ samples for the Weldox $700 \mathrm{E}$, the Weldox 960Q and the Alform $960 \mathrm{M}$ base materials and their welded joints, determined from the certain kinetic diagrams, respectively. In that case when the kinetic diagram can be written with more straight section in the domains, then only the constants of the relationship which describes the greatest (middle) part of the diagram were used for the statistical samples. Wilcoxon matched pair test (testing the hypothesis that the scores for two variables were drawn from the same distribution) [19] were used for the assessing of the independency of the samples.
Fig. 11 Results of FCG tests executed on Alform 960M matching and undermatching welding condition in $23 \mathrm{~W}$ orientation

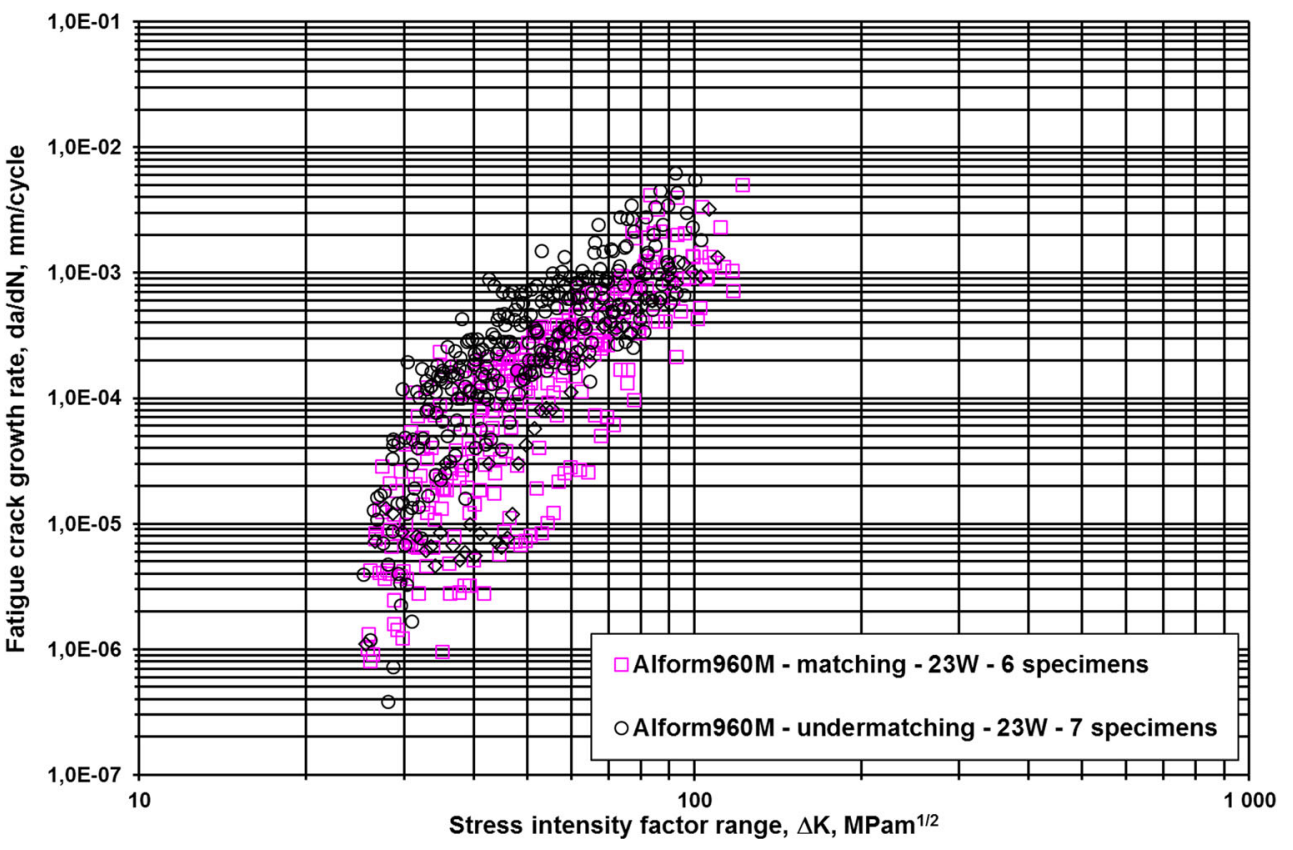


Table 5 Results of calculated Paris-Erdogan exponent $(n)$ and fatigue fracture toughness $\left(\Delta K_{f c}\right)$ samples from fatigue crack growth tests executed on Weldox 700E base material and their welded joints

\begin{tabular}{|c|c|c|c|c|c|}
\hline Base material, matching condition & Sample & $\begin{array}{l}\text { Element number of } \\
\text { sample }\end{array}$ & Average & $\begin{array}{l}\text { Standard } \\
\text { deviation }\end{array}$ & $\begin{array}{l}\text { Standard deviation } \\
\text { coefficient }\end{array}$ \\
\hline \multirow[t]{8}{*}{ Base material (BM) } & $n-T-L$ & 6 & 2.45 & 0.573 & 0.2337 \\
\hline & $n-L-T$ & 6 & 2.40 & 0.480 & 0.1999 \\
\hline & $\mathrm{n}-\mathrm{T}-\mathrm{L}$ and $\mathrm{L}-\mathrm{T}$ & 12 & 2.43 & 0.483 & 0.1991 \\
\hline & $\mathrm{n}-\mathrm{T}-\mathrm{S}$ & 6 & 2.19 & 0.922 & 0.4204 \\
\hline & $\Delta K_{f c}-T-L$ & 6 & 106.8 & 4.01 & 0.0375 \\
\hline & $\Delta K_{f c}-L-T$ & 6 & 106.9 & 3.30 & 0.0309 \\
\hline & $\begin{array}{l}\Delta \mathrm{K}_{\mathrm{fc}}-\mathrm{T}-\mathrm{L} \text { and } \\
\mathrm{L}-\mathrm{T}\end{array}$ & 12 & 106.9 & 3.35 & 0.0314 \\
\hline & $\Delta \mathrm{K}_{\mathrm{fc}}-\mathrm{T}-\mathrm{S}$ & 6 & 80.3 & 3.22 & 0.0401 \\
\hline \multirow[t]{4}{*}{ Welded joint (WJ), matching condition (m) } & $n-21 W$ & 6 & 5.10 & 0.600 & 0.1776 \\
\hline & $\mathrm{n}-23 \mathrm{~W}$ & 6 & 4.15 & 1.385 & 0.3334 \\
\hline & $\Delta \mathrm{K}_{\mathrm{fc}}-21 \mathrm{~W}$ & 6 & 117.2 & 7.70 & 0.0657 \\
\hline & $\Delta K_{\mathrm{fc}}-23 \mathrm{~W}$ & 6 & 87.0 & 4.32 & 0.0496 \\
\hline \multirow{4}{*}{$\begin{array}{l}\text { Welded joint (WJ), overmatching condition } \\
\text { (om) }\end{array}$} & $\mathrm{n}-21 \mathrm{~W}$ & 6 & 3.68 & 1.452 & 0.3944 \\
\hline & $\mathrm{n}-23 \mathrm{~W}$ & 6 & 3.43 & 1.166 & 0.3406 \\
\hline & $\Delta K_{\mathrm{fc}}-21 \mathrm{~W}$ & 6 & 110.1 & 9.57 & 0.0869 \\
\hline & $\Delta K_{\mathrm{fc}}-23 \mathrm{~W}$ & 6 & 86.3 & 16.55 & 0.1917 \\
\hline
\end{tabular}

Italic characters indicate in the tables the non-independent samples; these samples can be combined into one sample.

The element number of the samples, the average, the standard deviation and the standard deviation coefficient values can be found in the tables. Because both base materials and welded joints were investigated, the standard deviation coefficient values represent reliable measurements.

\section{Fatigue crack propagation limit curves}

Based on the experimental data and results, fatigue crack propagation limit curves can be determined. Generally, the determination of the fatigue design curves consists of six steps, as follows [20]. First step: determination of measuring values, the threshold stress intensity factor

Table 6 Results of calculated Paris-Erdogan exponent $(n)$ and fatigue fracture toughness $\left(\Delta K_{f c}\right)$ samples from fatigue crack growth tests executed on Weldox 960Q base material and their welded joints

\begin{tabular}{llllll}
\hline Base material, matching condition & Sample & Element number of sample & Average & Standard deviation & Standard deviation coefficient \\
\hline Base material (BM) & $n-T-S$ & 5 & 3.96 & 0.946 & 0.2390 \\
& $n-L-S$ & 5 & 3.74 & 0.273 & 0.0731 \\
& $\mathrm{n}-\mathrm{T}-\mathrm{S}$ and L-S & 10 & 3.85 & 0.667 & 0.1734 \\
& $\mathrm{n}-\mathrm{T}-\mathrm{L}$ & 5 & 2.44 & 0.615 & 0.2519 \\
& $\Delta K_{f c}-T-S$ & 5 & 100.2 & 6.69 & 0.0667 \\
& $\Delta K_{f c}-L-S$ & 5 & 102.7 & 4.57 & 0.0446 \\
Welded joint (WJ), & $\Delta \mathrm{K}_{\mathrm{fc}}-\mathrm{T}-\mathrm{S}$ and L-S & 10 & 101.5 & 5.55 & 0.0547 \\
matching condition $(\mathrm{m})$ & $\Delta \mathrm{K}_{\mathrm{fc}}-\mathrm{T}-\mathrm{L}$ & 5 & 125.1 & 8.39 & 0.0670 \\
& $n-21 W$ & 8 & 4.45 & 0.594 & 0.134 \\
& $n-23 W$ & 7 & 4.19 & 1.106 & 0.264 \\
& $\mathrm{n}-21 \mathrm{~W}$ and $23 \mathrm{~W}$ & 15 & 4.32 & 0.847 & 0.196 \\
& $\Delta K_{f c}-21 W$ & 8 & 115.5 & 113.20 & 0.114 \\
& $\Delta K_{f c}-23 W$ & 7 & 103.5 & 14.91 & 0.144 \\
\hline
\end{tabular}


Table 7 Results of calculated Paris-Erdogan exponent $(n)$ and fatigue fracture toughness $\left(\Delta K_{f c}\right)$ samples from fatigue crack growth tests executed on Alform $960 \mathrm{M}$ base material and their welded joints

\begin{tabular}{llllll}
\hline Base material, matching condition & Sample & $\begin{array}{l}\text { Element number of } \\
\text { sample }\end{array}$ & Average $\begin{array}{l}\text { Standard } \\
\text { deviation }\end{array}$ & $\begin{array}{l}\text { Standard deviation } \\
\text { coefficient }\end{array}$ \\
\hline Base material (BM) & $n-T-L$ & 6 & 2.35 & 0.396 & 0.1687 \\
& $n-L-T$ & 5 & 2.13 & 0.292 & 0.1372 \\
& $\mathrm{n}-\mathrm{T}-\mathrm{L}$ and L-T & 11 & 2.25 & 0.355 & 0.1581 \\
& $\mathrm{n}-\mathrm{T}-\mathrm{S}$ & 6 & 3.84 & 1.435 & 0.3735 \\
& $\Delta K_{\mathrm{fc}}-T-L$ & 6 & 139.4 & 14.85 & 0.1065 \\
& $\Delta K_{f c}-L-T$ & 5 & 122.1 & 5.03 & 0.0412 \\
& $\Delta \mathrm{K}_{\mathrm{fc}}-\mathrm{T}-\mathrm{L}$ and & 11 & 131.5 & 14.21 & 0.1080 \\
& $\mathrm{~L}-\mathrm{T}$ & & 102.3 & 9.37 & 0.0916 \\
Welded joint (WJ), matching condition (m) & $\Delta \mathrm{K}_{\mathrm{fc}}-\mathrm{T}-\mathrm{S}$ & 6 & 2.43 & 0.383 & 0.1580 \\
& $\mathrm{n}-21 \mathrm{~W}$ & 6 & 2.94 & 0.850 & 0.2157 \\
& $\mathrm{n}-23 \mathrm{~W}$ & 6 & 126.6 & 11.34 & 0.0986 \\
& $\Delta \mathrm{K}_{\mathrm{fc}}-21 \mathrm{~W}$ & 6 & 106.5 & 14.17 & 0.1331 \\
& $\Delta \mathrm{K}_{\mathrm{fc}}-23 \mathrm{~W}$ & 6 & 2.85 & 0.344 & 0.1207 \\
Welded joint (WJ), undermatching condition & $\mathrm{n}-21 \mathrm{~W}$ & 6 & 3.23 & 0.911 & 0.2819 \\
(um) & $\mathrm{n}-23 \mathrm{~W}$ & 7 & 122.6 & 9.710 & 0.0742 \\
& $\Delta \mathrm{K}_{\mathrm{fc}}-21 \mathrm{~W}$ & 6 & 96.5 & 11.05 & 0.1146 \\
\hline & $\Delta \mathrm{K}_{\mathrm{fc}}-23 \mathrm{~W}$ & 7 & & & \\
\hline
\end{tabular}

range $\left(\Delta K_{t h}\right)$, the two parameters of the Paris-Erdogan law $(C$ and $n)$ and the fatigue fracture toughness $\left(\Delta K_{f c}\right)$. Second step: classification of measured values into statistical samples, on the basis of calculated test results, applying Wilcoxon matched pairs test. Third step: selection of the distribution function type using Shapiro-Wilk, Kolmogorov-Smirnov and chi-square goodness of fit tests (testing if sample data fits a distribution from a certain population, i.e. a population with a normal or a Weibull distribution), at a level of significance $\varepsilon=0.05$. After the analysis, it was concluded, that only the three parameter Weibull-distribution function is suitable for describing all the configured samples. Fourth step: calculation of the parameters of the three parameter Weibull-distribution functions. The parameters of the distribution functions were calculated for all the configured samples using the

$F(x)=1-\exp \left[-\left(\frac{x-N_{0}}{\beta}\right)^{\frac{1}{\alpha}}\right]$

equation, where $N_{0}$ is the threshold parameter, $\alpha$ is the shape parameter and $\beta$ is the scale parameter. Fifth step: selection of the characteristic values of the distribution functions. Considering the influencing effects of the material parameters on life-time estimation, characteristic values of $\Delta K_{t h}, n$ and $\Delta K_{f c}$ were selected. The threshold stress intensity factor range $\left(\Delta K_{t h}\right)$ is that value which belongs to the $95 \%$ probability, the exponent of the
Paris-Erdogan law $(n)$ is that value which belongs to the $5 \%$ probability and the fatigue fracture toughness $\left(\Delta K_{f c}\right)$ is that value which belongs to the $5 \%$ probability of the relevant Weibull-distribution function. The Paris-Erdogan constant $(C)$ can be calculated on the material group (e.g. steels, aluminium alloys) dependent correlation between $C$ and $n$. The calculated data and the correlation of the presented results can be seen in Fig. $12(r=0.9955)$. Figure 13 shows the fifth step schematically. Sixth step: calculation of the parameters of the limit curves, using simplified method [21].

The main characteristics of the determined limit curves can be found in Table 8. In those cases, when the orientation and/ or the path of the propagating crack is known, the values in Table 8 can be directly used. In those cases, when $n$ and $\Delta K_{f c}$ values calculated in the two directions (T-L and L-T vs. T-S, or $21 \mathrm{~W}$ vs. $23 \mathrm{~W}$ ) are significantly different, and the orientation and/or the growing crack path is not known, the lowest value should be considered from the related ones. The unambiguous determination of the design curves in the near threshold region is difficult. On the one hand, if the threshold stress intensity factor range value $\left(\Delta K_{t h}\right)$ is not known, values can be found in the literature (e.g. $[22,23])$ are usable; furthermore, in special or particular cases, results of virtual testing [24] can be applied, too. On the other hand, the threshold stress intensity factor range value, $\Delta K_{t h}$, must be reduced by tensile residual stress field and may be increased by compressive residual stress field (e.g. welding residual stresses). 
Fig. 12 Connection between the Paris-Erdogan constants of the investigated materials

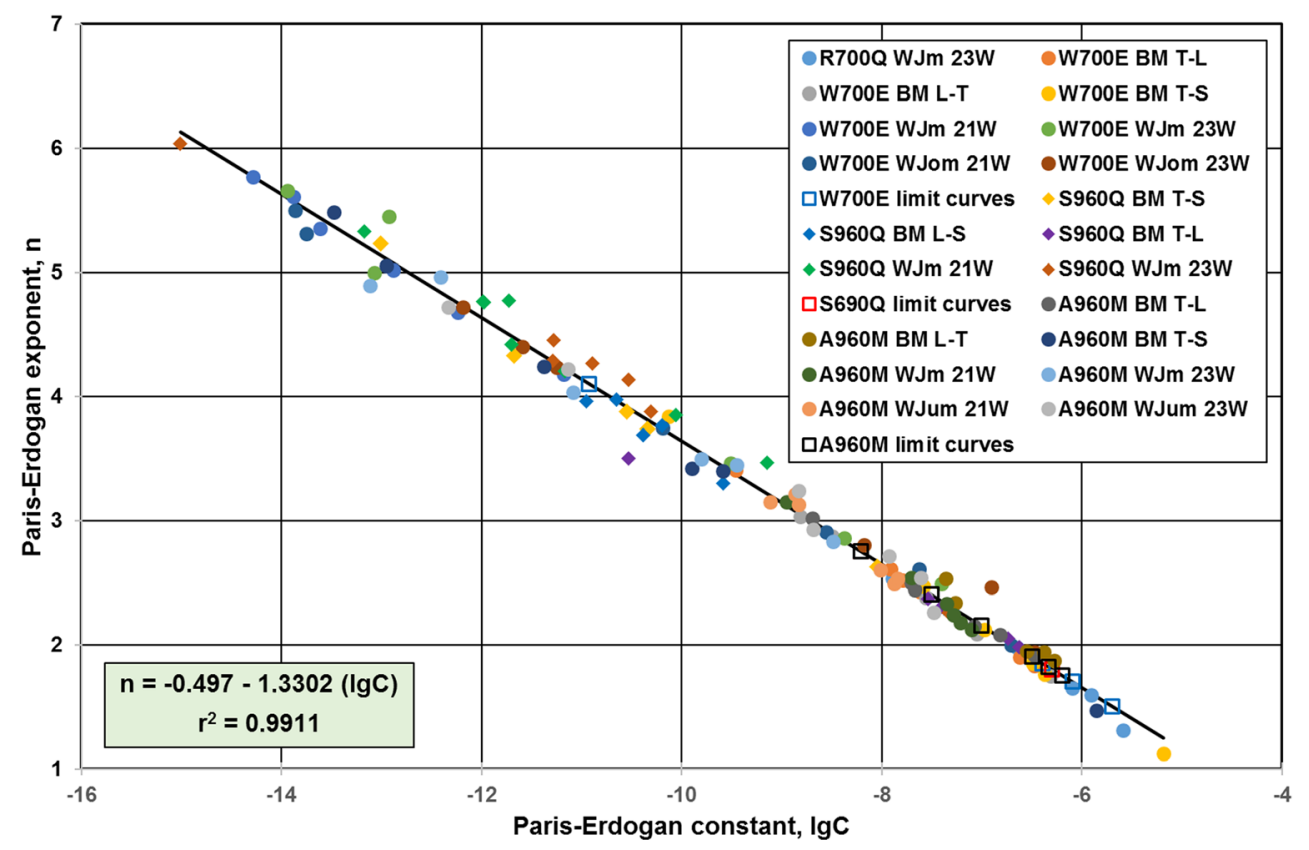

\section{Summary and conclusions}

Based on our investigations and their results, the following conclusions can be drawn.

- The applied gas metal arc welding process and the used technological parameters are suitable for production welded joints with appropriate quality.

- The welding causes unfavourable effects both on the mechanical properties and the fatigue crack growth resistance of the high-strength steels. This statement has good

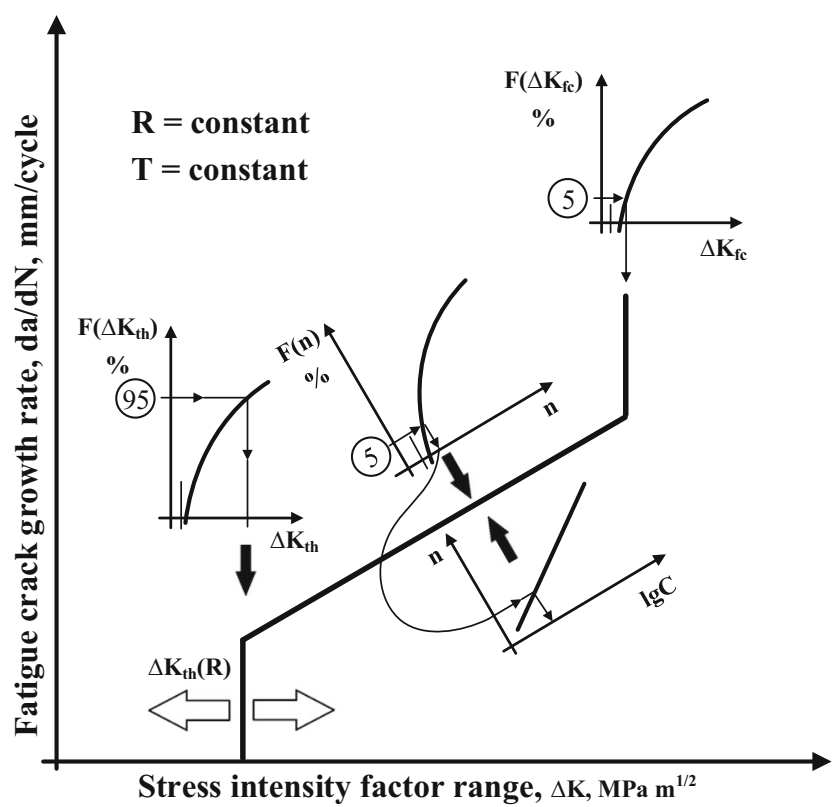

Fig. 13 Determination of fatigue crack propagation limit curves correspondence with previous high cycle fatigue experiments [25-27].

- The average values of the Paris-Erdogan exponents $(n)$ of Weldox 700E and Alform $960 \mathrm{M}$ base materials in the T-L and L-T directions and of the Weldox 960Q base material in the T-S and L-S directions are significantly not different, which means equal fatigue crack growth resistance in these orientations. The average values of the ParisErdogan exponent $(n)$ of Weldox 700E and Alform $960 \mathrm{M}$ base materials in the T-S orientation and of the Weldox 960Q base material in the T-L orientation are significantly different. The fatigue crack growth resistance of the Weldox 700E material is more unfavourable in T-S direction. The material strength category and the production condition $(\mathrm{Q}+\mathrm{T}$ and $\mathrm{TM})$ cause significant effect on the fatigue crack growth resistance, too.

- The average values of the Paris-Erdogan exponents $(n)$ of the matching (m), overmatching (om) and undermatching (um) conditions of the investigated welded joints were statistically higher than the exponents of the concerning base materials. The average value of the Paris-Erdogan exponent $(n)$ of the overmatching (om) welded joint of the Weldox $700 \mathrm{E}$ is lower than the exponent of the matching $(\mathrm{m})$ condition. The fatigue crack growth resistance under overmatching (om) condition is lower than matching (m) condition. The average value of the Paris-Erdogan exponent $(n)$ of the matching $(\mathrm{m})$ welded joint of the Alform $960 \mathrm{M}$ is lower than the exponent of the undermatching (um) condition. The fatigue crack growth resistance under matching $(\mathrm{m})$ condition is lower than undermatching (um) condition. 
Table 8 Characteristics of the determined fatigue crack propagation limit curves

\begin{tabular}{|c|c|c|c|c|c|}
\hline \multirow[t]{2}{*}{$\begin{array}{l}\text { Base } \\
\text { material }\end{array}$} & \multirow[t]{2}{*}{ Base material, matching condition } & \multirow[t]{2}{*}{ Orientation } & \multicolumn{2}{|c|}{$\begin{array}{l}\text { Parameters of the } \\
\text { Paris-Erdogan } \\
\text { law }\end{array}$} & \multirow{2}{*}{$\begin{array}{l}\text { Fatigue fracture } \\
\text { toughness } \\
\Delta \mathrm{K}_{\mathrm{fc}} \\
\left(\mathrm{MPam}^{1 / 2}\right)\end{array}$} \\
\hline & & & $\begin{array}{l}\mathrm{n} \\
(\mathrm{mm} / \mathrm{c} \\
\mathrm{MPan}\end{array}$ & $\begin{array}{l}\mathrm{C} \\
\text { cle, } \\
1 / 2)\end{array}$ & \\
\hline \multirow{6}{*}{$\begin{array}{l}\text { Weldox } \\
700 \mathrm{E}\end{array}$} & \multirow[t]{2}{*}{ Base material (BM) } & T-L and L-T & 1.70 & 8.09E-07 & 101 \\
\hline & & $\mathrm{T}-\mathrm{S}$ & 1.50 & $2.06 \mathrm{E}-06$ & 75 \\
\hline & \multirow{2}{*}{$\begin{array}{l}\text { Welded joint }(\mathrm{WJ}) \text {, matching } \\
\text { condition }(\mathrm{m})\end{array}$} & $21 \mathrm{~W}$ & 4.10 & $1.12 \mathrm{E}-11$ & 105 \\
\hline & & $23 \mathrm{~W}$ & 2.30 & 4.93E-08 & 80 \\
\hline & \multirow{2}{*}{$\begin{array}{l}\text { Welded joint (WJ), overmatching } \\
\text { condition (om) }\end{array}$} & $21 \mathrm{~W}$ & 1.85 & 4.02E-07 & 96 \\
\hline & & $23 \mathrm{~W}$ & 1.90 & 3.19E-07 & 61 \\
\hline \multirow[t]{2}{*}{$\begin{array}{r}\text { Weldox } \\
960 \mathrm{Q}\end{array}$} & Base material (BM) & $\begin{array}{l}\text { T-S, L-S, } \\
\quad \text { and T-L }\end{array}$ & 1.80 & $3.50 \mathrm{E}-07$ & 94 \\
\hline & $\begin{array}{l}\text { Welded joint (WJ), matching } \\
\text { condition }(\mathrm{m})\end{array}$ & $\begin{array}{l}21 \mathrm{~W} \text { and } \\
23 \mathrm{~W}\end{array}$ & 2.75 & $1.03 \mathrm{E}-08$ & 93 \\
\hline \multirow{6}{*}{$\begin{array}{l}\text { Alform } \\
960 \mathrm{M}\end{array}$} & \multirow[t]{2}{*}{ Base material $(\mathrm{BM})$} & T-L and L-T & 1.82 & 4.63E-07 & 116 \\
\hline & & $\mathrm{T}-\mathrm{S}$ & 1.75 & $6.41 \mathrm{E}-07$ & 87 \\
\hline & \multirow{2}{*}{$\begin{array}{l}\text { Welded joint }(\mathrm{WJ}), \text { matching } \\
\text { condition }(\mathrm{m})\end{array}$} & $21 \mathrm{~W}$ & 1.90 & 3.19E-07 & 114 \\
\hline & & $23 \mathrm{~W}$ & 2.75 & $6.06 \mathrm{E}-09$ & 82 \\
\hline & \multirow{2}{*}{$\begin{array}{l}\text { Welded joint (WJ), undermatching } \\
\text { condition (um) }\end{array}$} & $21 \mathrm{~W}$ & 2.40 & $3.10 \mathrm{E}-08$ & 115 \\
\hline & & $23 \mathrm{~W}$ & 2.15 & $9.93 \mathrm{E}-08$ & 67 \\
\hline
\end{tabular}

- The determined results fundamentally refer to reliable and reproducible examinations. Unfortunately, the standard deviation coefficients are in some cases too high (ParisErdogan exponent (n), T-S, $21 \mathrm{~W}$ and $23 \mathrm{~W}$ orientations).

- Based on these results and the used methods fatigue crack propagation limit curves can be determined for the investigated base materials and their gas metal arc welded joints, using simplified method [21]. The limit curves correctly reflect the fatigue crack growth characteristics of the base materials and the welded joints.

- Further examinations required to measuring $\Delta K_{t h}$ values for base materials and welded joints, to statistically more established conclusions and to study of the effects of the welding residual stress fields.

Acknowledgements Open access funding provided by University of Miskolc (ME). The described article was carried out as part of the EFOP-3.6.1-16-2016-00011 "Younger and Renewing University Innovative Knowledge City - institutional development of the University of Miskolc aiming at intelligent specialisation" project implemented in the framework of the Széchenyi 2020 program. The realization of this project is supported by the European Union, co-financed by the European Social Fund.

Open Access This article is distributed under the terms of the Creative Commons Attribution 4.0 International License (http:// creativecommons.org/licenses/by/4.0/), which permits unrestricted use, distribution, and reproduction in any medium, provided you give appropriate credit to the original author(s) and the source, provide a link to the Creative Commons license, and indicate if changes were made.

\section{References}

1. Balogh A, Lukács J, Török I (eds) (2015) Weldability and the properties of the welded joints. University of Miskolc, Miskolc (in Hungarian)

2. European Steel Technology Platform Vision 2030, Report of the Group of Personalities, EUROPEAN COMMISSION, Directorate-General for Research, Directorate Industrial Technologies, Unit G/05 Research Fund for Coal and Steel (March 2004). https://publications.europa.eu/en/ publicationdetail/-/publication/af1a9fd2-e4a5-4f1b-b74807075eedcf47. Accessed 01 July 2019

3. A Steel Roadmap for a Low Carbon Europe 2050, EUROFER The European Steel Association (2013) http://www. nocarbonnation.net/docs/roadmaps/2013-Steel_Roadmap.pdf. Accessed 01 July 2019

4. Baluch N, Udin ZM, Abdullah CS (2014) Advanced high strength steel in auto industry: an overview. Eng Technol Appl Sci Res 4(4): 686-689

5. Miller WS, Zhuang L, Bottema J, Wittebrood AJ, De Smet P, Haszler A, Vieregge A (2000) Recent development in aluminium alloys for the automotive industry. Mater Sci Eng A 280:37-49

6. Mazumdar S (2015) Driving Fuel Efficiency in the Automotive Industry Using Composites. https://www.compositeseurope.com/ d1/21/download/pdf/CE2016-Vortrag2015-Lucintel.pdf. Accessed 01 July 2019

7. Blacha S, Wegkowski MS, Dymek S, Kopyscianski M (2017) Microstructural and mechanical characterization of electron beam welded joints of high strength S960QL and Weldox 1300 steel grades. Arch Metall Mater 62(2):627-634. https://doi.org/10. 1515/amm-2017-0092

8. de Jesus AMP, Matos R, Fontoura BFC, Rebelo C, da Silva LS, Veljkovic M (2012) A comparison of the fatigue behavior between S355 and S690 steel grades. J Constr Steel Res 79:140-150 
9. Laurito DF, Baptista CARP, Torres MAS, Abdalla AJ (2010) Microstructural effects on fatigue crack growth behavior of a microalloyed steel. Pro Eng 2:1915-1925

10. Ravi S, Balasubramanian V, Nasser SN (2004) Effect of mis-match ratio (MMR) on fatigue crack growth behaviour of HSLA steel welds. Eng Fail Anal 11:413-428

11. Ravi S, Balasubramanian V, Babu S, Nasser SN (2004) Influences of MMR, PWHT and notch location on fatigue life of HSLA steel welds. Eng Fail Anal 11:619-634

12. Ravi S, Balasubramanian V, Babu S, Nasser SN (2004) Assessment of some factors influencing the fatigue life of strength mis-matched HSLA steel weldments. Mat Des 25:125-135

13. Gáspár M, Balogh A (2014) Behaviour of mismatch welded joints when undermatching filler metal is used. Prod Process Syst 7(1): 63-76

14. Gáspár M, Balogh A (2013) GMAW experiments for advanced (Q+ T) high strength steels. Prod Process Syst 6(1):9-24

15. Gáspár M, Balogh A, Sas I (2015) Physical simulation aided process optimisation aimed sufficient HAZ toughness for quenched and tempered AHSS. Proc IIW 2015 Int Conf, Paper IIW 2015 1504:1-7

16. Májlinger K, Borók A, Pasquale RS, Varbai B (2016) TIG welding of advanced high strength sheets. Proc 4th Int Scient Conf on Adv Mech (ISCAME 2016):313-318

17. ASTM E647 (2015) Standard Test Method for Measurement of Fatigue Crack Growth Rates. Annual Book of ASTM Standards, Vol. 03.01. ASTM, West Conshohocken, PA, USA

18. Paris P, Erdogan F (1963) A critical analysis of crack propagation laws. J Basic Eng, Trans ASME 85:528-534

19. Owen DB (1973) Handbook of statistical tables. Vychislitel'nyjj Centr AN SSSR, Moskva (in Russian)
20. Lukács J (2003) Fatigue crack propagation limit curves for different metallic and non-metallic materials. Mater Sci Forum 414-415:31-36

21. BS 7910:2013+A1:2015 (2015) Guide to methods for assessing the acceptability of flaws in metallic structures BSI Standards Limited

22. Ritchie RO (1979) Near-threshold fatigue-crack propagation in steels. Int Mater Rev 24(5-6):205-230

23. Taylor D, Jianchun L (eds) (1993) Sourcebook on fatigue crack propagation: threshold and crack closure. EMAS, Warley

24. Farahmand B (2008) Application of virtual testing for obtaining fracture allowable of aerospace and aircraft materials. In: Sih GC (ed) Multiscale fatigue crack initiation and propagation of engineering materials: structural integrity and microstructural worthiness, solid mechanics and its applications 152, 1st edn. Springer, Dordrecht, pp 1-22

25. Marines-García I, Galván-Montiel D, Bathias C (2008) Fatigue life assessment of high-strength, low-alloy steel at high frequency. Arabian J Sci Eng 33(1B):237-247

26. Pijpers RJM, Kolstein MH, Romeijn A, Bijlaard FSK (2007) Fatigue experiments on very high strength steel base material and transverse butt welds. Adv Steel Constr 5(1):14-32

27. Hamme U, Hauser J, Kern A, Schriever U (2000) Einsatz hochfester Baustähle im Mobilkranbau. Stahlbau 69(4):295-305

Publisher's note Springer Nature remains neutral with regard to jurisdictional claims in published maps and institutional affiliations. 